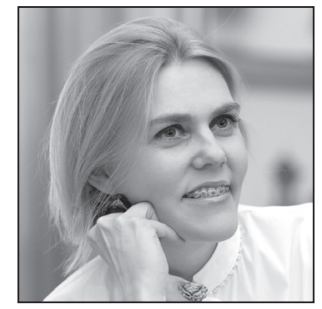

Julia Laffranque

\title{
European Human Rights Law and Estonia: One- or Two-way Street?
}

\section{Historical background: Ratification of the convention and its protocols by Estonia}

After re-gaining its independence in 1991, Estonia was eager to confirm the country's historical belonging to Europe and opened itself up to a democratisation process. All efforts were taken in order to return Estonia to the family of democratic states governed by the rule of law and again join the international community, including the Council of Europe (on 14 May 1993) and later on the EU (on 1 May 2004). European human rights law as understood for the purpose of this article is above all the European Convention on Human Rights and Fundamental Freedoms (the Convention) and the case law of the European Court of Human Rights (the Court, the Strasbourg Court) in applying and interpreting it.

Lennart Meri, President of Estonia in 1992-2001, in the first years of the re-established Republic of Estonia (in the 1990s) pointedly warned that if we do not build a state governed by the rule of law, Estonia will be as lonely as the Moon rotating around the Earth. ${ }^{{ }_{1}}$

Estonia ratified the Convention on 13 March 1996 and it became binding for Estonia as of 16 April 1996. A reservation to the Convention was made by the Government of Estonia regarding Article 1 of Protocol No. 1 of the Convention as far as Estonian laws on property reform are concerned. The reservation turned out to be a pragmatic choice, because in Estonia some property-reform-related issues are many years later still not solved. In its decision in the case Shestjorkin $v$. Estonia ${ }^{{ }_{2}}{ }_{2}$ which concerned the restitution of nationalised property, the Court examined Estonia's reservation and found that it satisfied the requirements of the Convention. The European Commission of Human Rights had already held the reservation applicable and the application inadmissible in another Estonian property reform case. ${ }^{*} 3$ Despite this reservation, the case law of the national judiciary, especially of the Supreme Court and its Administrative Law Chamber, has followed the principles of rule of law and found them to be applicable also in often both factually and legally very complicated cases of privatisation. On the other hand, the Court has even without going necessarily into the substance of the Estonian reservation accepted that the national authorities enjoyed a wide margin of appreciation in regulating ownership relations that involved large-scale economic and legal reforms and that the national authorities succeeded in striking a fair balance between the proprietary interests of the persons concerned. ${ }^{4}$

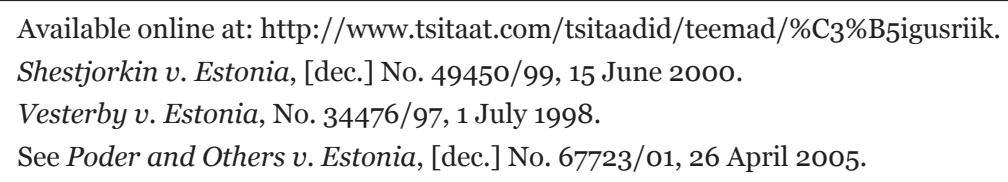


Protocol No. 6 to the Convention, concerning the abolition of the death penalty, was ratified by Estonia on 18 March $1998 .{ }^{*}$ It was a big step towards democracy and an important milestone in the protection of human rights in Estonia because the death penalty was previously provided by national law, although it had for the very last time been executed in September 1991, when re-independent Estonia was only about a month old. The death penalty was then replaced by life imprisonment. Protocol No. 13 to the Convention, concerning the abolition of the death penalty in all circumstances (CETS No. 187), was ratified by Estonia on 12 November 2003. ${ }^{* 6}$

Estonia has so far not ratified Protocol No. 12 to the Convention, about the general prohibition of discrimination, although it signed the Protocol on 4 November 2000.

Protocol No. 15, adopted on 24 June 2013, was signed by Estonia on 22 October 2013 and ratified on 30 April 2014. Protocol No. 16, adopted on 2 October 2013 and aimed at enhancing the dialogue between the Court and national courts in the framework of non-binding advisory opinions, has been signed by Estonia (on 17 February 2014) but is not yet ratified as of January 2015.

\section{Status of the Convention in the Estonian legal order}

Formally, in Estonia the Convention is seen as a ratified international treaty. The Convention is an integral part of the Estonian legal order; it is positioned above any other legal act in the hierarchy of legal sources in Estonia except the Constitution of the Republic, adopted by the Estonian people on 28 June 1992. The status of an international treaty is regulated by $\$ 123$ of the Estonian Constitution, which stipulates that Estonia shall not enter into international treaties that are in conflict with the Constitution. Furthermore, the same section emphasises that if laws or other legislation of Estonia is in conflict with international treaties ratified by the Estonian Parliament, the provisions of the international treaty shall apply.

In practice, the Convention and the Court's case law interpreting it are the standard, together with the Constitution, by which alleged violations of human rights are ascertained by the Supreme Court of Estonia. Moreover, at the same time the text of the second chapter of the Estonian Constitution ("Protection of fundamental rights, freedoms and obligations") is based to a large extent on the Convention, even though no direct reference to the Convention is made. According to $\$ 3$ of the Estonian Constitution, universally recognised principles and rules of international law are an inseparable part of the Estonian legal system.

As early as in 1994, thus about two years before the Convention became binding for Estonia (and as much as 10 years before Estonia's accession to the European Union (EU)), the Supreme Court of Estonia had emphasised that the general principles of law developed by the institutions of the Council of Europe and the EU should be taken into consideration alongside the Estonian Constitution. ${ }^{*} 7$

The Criminal Law Chamber of the Supreme Court stressed in its judgement of 20 September 2002 the position of the Convention in the Estonian legal system, noting that, on the basis of $\S 3$ (2) and $\S 123$ (2) of the Constitution, the Convention and the rulings of the Court in interpretation thereof form an integral part of the Estonian legal system, having priority with regard to Estonian laws. The Chamber added that in certain cases the Convention can also provide assistance in furnishing the concept of the Estonian Constitution. ${ }^{*}$

On 6 January 2004 the Supreme Court en banc pointed out in its judgement in a criminal case that the Convention constitutes an inseparable part of the Estonian legal order and that to guarantee the rights and freedoms set forth in the Convention is, under Article 14 of the Constitution, also the duty of the (Estonian) judicial power. ${ }^{*} 9$

$5 \quad$ Inimõiguste ja põhivabaduste kaitse konventsiooni lisaprotokolli $\mathrm{nr} 6$ ratifitseerimise seadus (Act Ratifying Additional Protocol No. 6 to the Convention for the Protection of Human Rights and Fundamental Freedoms). Adopted on 18.03.1998, RT II 1998, 14, 22.

6 Euroopa inimõiguste ja põhivabaduste kaitse konventsiooni protokolli nr 13 surmanuhtluse igas olukorras kaotamise kohta ratifitseerimise seadus (Act Ratifying Protocol No. 13 of the European Convention for the Protection of Human Rights and Fundamental Freedoms concerning the Abolition of Death Penalty in All Circumstances). Adopted on 12.11.2003, RT II 2003, 31, 156 .

7 The Supreme Court stated in a judgement concerning the review of the constitutionality of Article 25, paragraph 3 of the Property Law Enforcement Act that the general principles of law developed by the institutions of the Council of Europe and of the EU form part of the sources of Estonian law, Decision of 30 September 1994 of the Constitutional Review Chamber of the Supreme Court, Case No. III-4/A-5/94. - RT 1 1994, 80, 1159.

8 Judgement of 20 September 2002 of the Criminal Law Chamber of the Supreme Court, Case No. 3-1-1-88-02.

9 Judgement of 6 January 2004 of the Supreme Court en banc, Case No. 3-1-3-13-03. 


\section{Impact of the Court's case law on the Estonian legislature, executive power, and judiciary}

The first judgement of the Court concerning Estonia was delivered on 12 September 2000 in the case Slavgorodski $v$. Estonia ${ }^{* 10}$ (there had been inadmissibility decisions before) and concerned opening by the prison administration of the letters from the European Commission of Human Rights to the applicant, who was a prisoner. The application was declared admissible ${ }^{* 11}$, but later the case was struck from the list due to the friendly settlement reached between the parties.

As of March 2015, in little less than 20 years under the Court's jurisdiction, 44 judgements in all have been rendered by the Court in respect of Estonia. The vast majority of them have been on criminal matters, few on civil and administrative cases (although one must specify that the issues of prison conditions are dealt with in Estonia by the administrative courts). Most of them have found a violation of the Convention by Estonia (violations have been found as far as Articles 3, 5, 6, 7, 8, and 13 and Article 1, Protocol No. 1 are concerned; most of the violations found are related to the right to liberty and security (Article 5 of the Convention), and to fair trial issues (Article 6 of the Convention) as well as to a certain extent to the length of proceedings.

The number of decisions finding that the application was inadmissible by a chamber of the Court in respect of Estonia is at the same time 28. Most of the applications are declared inadmissible by a single judge.

The average number of applications allocated per 10,000 inhabitants in respect of Estonia in 2014 was 1.42. This is well above the average of the whole Council of Europe, which in the same year was 0.68. The Council of Europe Member States had in 2013 a combined population of approximately 822 million inhabitants, whereas on 1 January 2012 Estonia had approximately 1.34 million of these.

\section{Problems from the historic past}

there are some questions related particularly to Estonia and perhaps to a certain extent also other Eastern European countries, on such matters as the bitter experiences and remnants from the Soviet occupations, including the issues emerging from the past in connection with the deportation of Estonians to Siberia and the retroactivity of a criminal punishment linked to a conviction for crimes against humanity; the presence of Soviet army pensioners and other Russian-speaking residents in Estonia; problems with the associated pension system, residence permit matters, and migration issues; and even to some extent the riots caused by the relocation of a monument representing a Soviet soldier (the Bronze Soldier) from the city centre of Tallinn to a military cemetery approximately 16 years after the end of the Soviet occupation of Estonia. ${ }^{{ }^{1}}{ }^{2}$

In inadmissibility decisions in cases concerning the accordance with Article 7 of the Convention of the national criminal proceedings against applicants who participated in the deportation of the civilian population from Estonia to remote areas of the Soviet Union and in the case of an applicant who had planned and directed the killing of a person hiding in the woods from the repression by the Soviet authorities, the Court has expressis verbis recognised that Estonia was illegally occupied by the Soviet Union in 1940-1941 and in 1944-1991. ${ }^{*}{ }^{13}$ This constitutes an important stage in establishing the historical truth for which the Estonian people have waited for a long time. ${ }^{* 14}$

10 Slavgorodski v. Estonia, No. 37043/97, 12 September 2000.

11 Slavgorodski v. Estonia, final decision as to the admissibility, No. 37043/97, 9 March 1999.

12 Korobov and Others $v$. Estonia, No. 10195/o8, 28 March 2013. In this judgement a substantive violation in respect of one applicant and procedural violation (no effective investigation) in respect of four applicants of Article 3 of the Convention were found in connection with the actions of law enforcement officers during the riots following protests against the relocation of a monument commemorating the entry of the Soviet Red Army into Tallinn during the Second World War. However, the Article 5 (1) complaint of all applicants was declared inadmissible due to non-exhaustion.

13 Kolk and Kislyiy v. Estonia, [dec.] Nos 23052/04 and 24018/04, 17 January 2006 and Penart v. Estonia, No. 14685/04, 24 January 2006.

14 See also Mälksoo, Lauri, Euroopa Inimõiguste Kohtu (suurkoja) otsus asjas Kononov v. Läti (Judgment of the European Court of Human Rights (Grand Chamber) in the case Kononov v. Latvia (application No. 36376/04), Juridica 2011, No. 3 , pp. 232-236, p. 235 . 


\section{Deprivation of Liberty}

The violations found in respect of Article 5 (1), (3) and (4) of the Convention are related to reasoning for pre-trial detention, excessive and unreasonable length of pre-trial detention ${ }^{* 15}$ or detention in expulsion ${ }^{* 16}$, unjustified extensions thereof and lack of speedy examination of applications for release, matters related to the not bringing of a person before the national court immediately after his or her arrest, and lack of proper judicial control over deprivation of liberty, along with setting the requirements and standards for Estonian authorities' compliance with Article 5 (3) and (4) of the Convention. The Court emphasised that a person must be brought promptly before a judge also in cases where there existed an arrest warrant authorised by the court. These principles are now well enshrined in the respective current legislation in force in Estonia. ${ }^{* 17}$

There has been also a judgement of the Court finding a violation of Article 5 (1) of the Convention that concerned deprivation of an unsound person of liberty and where the Court did not agree with the Estonian authorities that the applicant was heard "promptly" after she had been signed up for compulsory admission. ${ }^{* 18}$

Presumably due to the constant case law of the Court upholding the values enshrined in Article 5 of the Convention, the Estonian regulation concerning pre-trial and pending-trial detention has become stricter the new Code of Criminal Procedure of Estonia (kriminaalmenetluse seadustik) introduced time limits for the period of pre-trial detention and a regular review thereof. ${ }^{*} 19$

On the other hand, in Ovsjannikov v. Estonia, ${ }^{*}{ }^{20}$ the Court found no violation of Article 5, §3 (six months of pre-trial detention) but pronounced a violation of Article 5 (4) of the Convention on account of neither the applicant nor his counsel having been given access to the evidence in the criminal case file presented by the prosecutor on the basis of which the court decided the lawfulness of the applicant's remanding in custody and his continued detention.

\section{Prison conditions}

In respect of Article 3 of the Convention, violations have been found due to poor, degrading, and inhuman prison conditions, in particular pre-trial detention and arrest facilities' conditions, such as overcrowded cells. The Court has also emphasised the need for protection of human rights of prisoners, including the principle that the state's responsibility is not limited to premeditated inhuman treatment and not limited only to intentional harm caused. ${ }^{* 1}$

One can say that indeed so far one of the biggest impacts of the Convention, of the Court's case law, and also of the CPT (European Committee for the Prevention of Torture) reports to Estonia has been the improvement of the conditions in Estonian prisons; as well as contribution to the development of the system of state responsibility and compensation caused by the poor prison conditions (e.g., Kochetkov $v$. Estonia, ${ }^{, 22}$ Julin v. Estonia ${ }^{* 23}$ ).

After the Alver $v$. Estonia judgement, new prisons were built, and after the Kochetkov v. Estonia judgement, the conditions in the arrest buildings were improved.

In the case Tunis $v$. Estonia ${ }^{* 24}$, the applicant suffered from back and neck pain, in an overcrowded cell he had difficulties doing the exercises prescribed by a doctor, and he had only limited out-of-cell activity of an hour of daily exercise in the outdoor exercise yard. He had spent more than two years and ten months

15 Sulaoja v. Estonia, No. 55939/oo, 15 February 2005; Pihlakv. Estonia, No. 73270/o1, 21 June 2005; Harkmann v. Estonia, 2192/o3, 11 July 2006; Bergmann v. Estonia, No. 38241/04, 29 May 2008; Ovsjannikov v. Estonia, No. 1346/12, 20 February 2014.

16 Mikolenko v. Estonia, No. 10664/o5, 8 October 2009.

17 See $\$ 131$ of the Estonian Code of Criminal Procedure on the procedure for taking into custody, especially amendments made in 2008 and 2011, e.g., RT I, 23.02.2011, 1 - entered into force on 1 September 2011.

18 S. v. Estonia, No. 17779/o8, 4 October 2011.

19 Sections 130 (the grounds for taking into custody and holding in custody); 131 (2); 136 and 137; and 275 (2) (detention pending trial) of the Code of Criminal Procedure adopted on 12 February 2003 and with the latest amendments as in force in January 2014.

20 Ovsjannikov v. Estonia, No. 1346/12, 20 February 2014.

21 For example Alver $v$. Estonia, No. 64812/01, 8 November 2005.

22 Kochetkov v. Estonia, No. 41653/05, 2 July 2009.

23 Julin v. Estonia, No. 16563/o8, 40841/o8, 8192/10, and 18656/10, 29 May 2012.

24 Tunis v. Estonia, No. 429/12, 19 December 2013. 
in those conditions, excluding short periods in other cells of the prison or the prison hospital. The Court considered that the conditions of the applicant's detention caused him suffering that exceeded the unavoidable level of suffering inherent in detention and found a violation of Article 3 of the Convention. Right after the judgement and inspired already by other, similar judgements of the Court in respect of other countries, new amendments to Regulation No. 72 of the Minister of Justice on the Internal Prison Rules (vangla sisekorraeeskiri) were made, which foresee at least 2.5 square metres of floor space per prisoner in a room and three square metres per cell. ${ }^{*} 5$

Nevertheless, on 20 June 2014 the Constitutional Review Chamber of the Supreme Court of Estonia decided that the 2.5 square metres of space foreseen for a prisoner neither as such nor together with other relevant legal stipulations contradicted the Estonian Constitution. However, at the same time the Supreme Court stressed that, all in all, the prison conditions of the applicant in that case could have violated the human dignity of the prisoner and in order to examine this it is important to look also at what were the real conditions of the prisoner and the out-of-cell activities at the time he spent in limited space. ${ }^{*} 6$

The right to public security and at the same time the need to guarantee fundamental rights has caused the Strasbourg Court to deal with cases concerning the proportionality of the use of force in prisons by the prison authorities against violent prisoners by means such as the restraint bed or tear gas ${ }^{* 27}$, and preservation of privacy during the strip searches ${ }^{* 28}$.

\section{Fair trial and length of proceedings}

another group of cases deal with the lessons to be learned as regards the fair trial and due process: access to the courts; equality of arms; lengthy proceedings and no effective remedy against this condition; questions of defence; and the right to a lawyer, including the right to the defence of one's own choosing; quality of the defence lawyer; questioning of witnesses, and presumption of innocence. Also the access of the defence to the investigation materials collected by covert surveillance measures has caused disputes (judgements such as those in Metsaveer v. Estonia ${ }^{* 29}$, Andreyev v. Estonia ${ }^{*} 30$, Martin v. Estonia ${ }^{*}{ }^{31}$, Vronchenko v. Estonia ${ }^{*}{ }^{32}$ and Rosin v. Estonia ${ }^{*} 33$, Taal v. Estonia ${ }^{*} 34$ and Pello v. Estonia ${ }^{*} 35$, as well as Leas v. Estonia ${ }^{*} 36$ are worth mentioning). In one case, a violation was found due to lack of impartiality of a judge because her husband had been involved in the pre-trial investigation of the same case concerning the applicants. ${ }^{*} 7$ Also a few problems of enforcement of national judgements have occurred; however, for reasons of friendly settlement by the parties or abuse by the applicant, the Court has never examined the merits of enforcement cases.

As far as the fair trial is concerned, the Court has found violations of Article 6 of the Convention because the applicants had been unable to question witnesses, be this during the pre-trial or in the court proceedings, due to the protection of victims of minor age (see the judgements in Vronchenko v. Estonia and Rosin

25 Vangla sisekorraeeskiri, adopted on 30 November 2000, RTL (Riigi Teataja Lisa) 2000, 134, 2139, latest amendments of 23 December 2013, RT I, 29.12.2013, 36. It remains to be seen whether these measures are efficient. According to the Minister of Justice, in 2013 Estonia had 3100 prisoners, which is too high compared to other countries; see Pevkur: Kas inimõiguste kohtu otsuse järgimine on kellegi arvates väär? (Pevkur: Is it Wrong to Follow the Judgement of the Human Rights Court?), Postimees, 14 November 2013.

26 Judgement of 20 June 2014 of the Constitutional Review Chamber of the Supreme Court, Case No. 3-4-1-9-1.

27 Julin v. Estonia, Nos 16563/o8, 40841/o8, 8192/10, and 18656/10, 29 May 2012; Tali v. Estonia, No. 66393/10, 13 February 2014.

28 As to the latter, see Jaeger $v$. Estonia, No. 1574/13, 31 July 2014, where the Court found that $\S 3$ of the Convention threshold was not met but the case fell within the scope of $\S 8$ of the Convention (right for respect for private life) and found in the circumstances of this case a violation of $\S 8$ because the applicant’s body search (strip search) took place on his return from a walk to the prison's accommodation section in a stairwell having two doors with uncovered transparent glass windows.

29 Metsaveer v. Estonia [dec.] no. 16343/07, 14 June 2011.

30 Andreyev v. Estonia, No. 48132/07, 22 November 2011.

31 Martin v. Estonia, No. 35985/09, 30 May 2013.

32 Vronchenko v. Estonia, No. 59632/o9, 18 July 2013.

33 Rosin v. Estonia, No. 26540/o8, 19 December 2013.

34 Taal v. Estonia, No. 13249/02, 22 November 2005.

35 Pello $v$. Estonia, No. 11423/03, 12 April 2007.

36 Leas v. Estonia, No. 59577/o8, 6 March 2012.

37 Dorozhko and Pozharskiy v. Estonia, Nos 14659/o4 and 16855/o4, 24 April 2008. 
v. Estonia). Today, these issues concerning the minors have been solved: according to the changes made in the Code of Criminal Procedure, $\$ 290^{1}$ (1) stipulates that a court may under certain circumstances not summon a minor and allow submission of the testimony given by the minor in pre-trial procedure as evidence, provided that the testimony was video recorded and that the counsel has had the opportunity to pose questions to the witness in pre-trial procedure about the facts related to the subject of proof.

In Leas $v$. Estonia the applicant had complained that the proceedings had been unfair as he had not been given access to a covert surveillance file on him that had led to the charges being brought against him and, subsequently, to his conviction. The Court did not consider the procedure employed to determine the issue of disclosure of evidence to have complied with the requirements to provide adversarial proceedings and equality of arms and found a violation of Article 6 (1) of the Convention.

It is important to note that in most of these cases either the national law or the practice of the Supreme Court has been changed in the meantime. The trend towards more Convention-confirming domestic law is welcoming. Judgements of the Court have also helped to improve the reasoning of judgements of Estonian courts that take into account the European principles and the Court's case law. The quality of judgements is certainly a strong point for further independence of the judiciary. ${ }^{*} 38$ On the other hand, the Supreme Court of Estonia has, in order to guarantee the independence of a judge, relied on Article 6 (1) of the Convention directly and has on its own initiative considered unconstitutional the absence of a legal regulation foreseeing the payment of salary or other compensation to a judge whose service has been stayed pending a criminal investigation. ${ }^{*} 39$

Concerning the length of proceedings, the Court has rendered the following judgements finding violations due to unreasonable time of national (all civil) proceedings (respectively, seven years and seven months; five years and ten months; more than seven years and two months; and six years, seven months, and 20 days): Treial v. Estonia, Shchiglitsov v. Estonia, (both only Article 6), Saarekallas OÜ v. Estonia, and Missenjov $v$. Estonia (both Article 6 and Article 13 of the Convention). ${ }^{*}{ }^{40}$ More recently, the Court found a violation of reasonable time in civil proceedings (division of joint property by divorcing) that lasted for nine years and nearly nine months for three levels of Estonian jurisdiction and, respectively, six years and three months for three levels of jurisdiction for civil proceedings concerning claim for alimony for the applicants' son in which special diligence was needed. ${ }^{*} 4$ In an administrative law case, Raudsepp $v$. Estonia, Article 13 violation of the Convention only on account of a missing remedy and not of Article 6 (1) for complicated property reform proceedings of nearly five years and eleven months' duration was found. ${ }^{*}{ }^{42}$ In addition to that, there have been friendly settlements and one unilateral declaration in this area. In criminal cases the Court has not found a violation for length of proceedings but has acknowledged the Estonian courts' practice of reducing defendants' sentences in cases of unreasonably lengthy criminal proceedings ${ }^{*} 43$ and concluded that to appeal within the criminal proceedings about the unreasonable length constitutes an effective remedy on national level that needs to be exhausted before addressing of the Strasbourg Court. ${ }^{*} 4$

On 27 January 2011, amendments to the Code of Criminal Procedure, \$274 ("Request to expedite court proceedings") and $\S 274^{2}$, which foresees a possibility to terminate criminal proceedings in court sessions in connection with expiry of a reasonable time of processing, were adopted. In that connection, also a new $\$ 333^{1}$ of the Code of Civil Procedure (tsiviilkohtumenetluse seadustik) was approved, establishing a whole set of measures directed at speeding up the proceedings on national level. These remedies were adopted under the clear influence of the judgements of the Court, as well as of the Supreme Court referring to the case law of the Court, and entered into force on 1 September 2011. Whether in the

38 See Opinions of the Consultative Council of European Judges, in particular Opinion No. 1 (2001) on standards concerning the independence of the judiciary and the irremovability of judges and Opinion No. 11 (2008) on the quality of judicial decisions.

39 Judgement of 14 April 2009 of the Supreme Court en banc, Case No. 3-3-1-59-07, para. 32.

40 Treial v. Estonia, No. 48129/99, 2 December 2003; Shchiglitsov v. Estonia, No. 35062/03, 18 January 2007; Saarekallas OÜ v. Estonia, No. 11548/04, 8 November 2007; Missenjov v. Estonia, No. 43276/o6. See also Susi, Mart, The Estonian Judicial System in Search of an Effective Remedy against Unreasonable Length of Proceedings, Juridica International, XVI, 2009, pp. 193-202, p. 202.

41 Kïsa v. Estonia, No. 72999/10 and nos. 16587/10 and 34304/11 of 18 February 2014.

42 Raudsepp v. Estonia, No. 54191/07, 8 November 2011.

43 Motsnik v. Estonia, No. 50533/99, 29 April 2003; Malkov v. Estonia, No. 31407/07, 4 February 2010; Mets v. Estonia, [dec.] no. 38967/10, 7 May 2013.

44 Velleste v. Estonia, [dec.] no. 67623/10, 4 January 2012 and Andrejev v. Estonia, [dec.] no. 64016/10, 4 January 2012 
future the non-exhaustion of these remedies could lead to inadmissibility by the Court ${ }^{*} 45$ remains still to be seen.

Also $\$ 100$ of the entirely new Code of Administrative Court Procedure (halduskohtumenetluse seadustik) ${ }^{*}$, which entered into force on 1 January 2012, bears the title: "Application to expedite court proceedings". In addition, the Courts Act (kohtute seadus), as modified, in $\S 45\left(1^{1}\right)$ gives the president of a court the right to decide on the implementation of a measure organising the administration of justice, which presumably provides the opportunity to finalise the proceedings within a reasonable period of time.

Regrettably, the other remedy - compensation for proceedings that have lasted for unreasonable time - has not yet been introduced into the State Liability Act. The Supreme Court en banc, proceeding from the Court's case law, in the judgement in the Osmjorkin ${ }^{*} 47$ case declared unconstitutional the lack of a regulatory framework that does not allow compensation for non-pecuniary damage caused by an unreasonably extended pre-trial criminal proceeding. At the same time the Supreme Court applied the Constitution directly and said that the compensation can in the meantime be sought by seizing the administrative courts. The Strasbourg Court considered in its case law in respect of Estonia that the enactment of legislation clearly establishing grounds and speedy procedures for awarding compensation for excessively lengthy proceedings would contribute considerably to legal certainty in this field. However, since the Court's task is not to assess a state's legislation - or its absence - in the abstract the Court considered for the time being as sufficient the temporary remedy created by the Supreme Court according to which the applicants can turn, in action based directly on the Estonian Constitution, to the administrative courts to ask for compensation, ${ }^{*} 48$ especially in view of the fact that in consecutive national judgements the Tartu administrative court granted the applicant's claim in part and awarded him compensation for the non-pecuniary damage caused by the excessive length of his criminal proceedings. ${ }^{*} 49$

\section{Pluralism and civil rights}

although so far there have been no judgements concerning elections in respect of Estonia, the Court has nevertheless had to deal with pluralism of expressions as such in finding the right balance between the freedom of expression and the right to a private life in media and thus in deciding about the possible limits of freedom of expression. The latter was obviously important to the society waking up from the Soviet past and ideological pressure.

In Tammer $v$. Estonia ${ }^{*} 5^{\circ}$ the Court had to balance between the journalist's freedom of expression and the protection of the private life of a well-known politician's wife. The journalist was convicted in Estonia for using insulting words. The Court found that there was no violation of Article 10 of the Convention because the use of terms by the journalist was not justified by considerations of public concern nor did they bear on a matter of general importance.

However, some time after the judgement decriminalisation in Estonian law of insult and defamation took place. Whether it is directly related to the proceedings in the case Tammer $v$. Estonia, which actually ended up with a judgement finding no violation of Article 10 of the Convention at the time the applicant was still criminally convicted for defamation, is difficult to conclude without going into deeper analyses of the preparatory legislative drafting materials, but it is definitely a welcoming development taking into account also the fact that the Council of Europe Parliamentary Assembly (PACE) calls for decriminalisation of defamation. ${ }^{*}{ }^{1}$

45 See Maris Kuurberg, Tõhusad õiguskaitsevahendid ebamõistlikult pika menetluse heastamiseks Eestis. Euroopa Inimõiguste Kohtus Eesti suhtes tehtud lahendid (Efficient Legal Remedies for Unreasonably Long Proceedings in Estonia: Judgements Made in the European Court of Human Rights in Respect of Estonia, Juridica (in Estonian), 2012, No. 9, pp. 677-683, pp. 681 and 683 .

46 RT I, 23 February 2011, 3.

47 Judgement of 22 March 2011 of the Supreme Court en banc, Case No. 3-3-1-85-09.

48 See Raudsepp v. Estonia, No. 54191/07, 8 November 2011.

49 See Mets $v$. Estonia [dec.], 38967/10, 7 May 2013.

5o Tammer $v$. Estonia, No. 41205/98, 6 February 2001.

51 Resolution of the Council of Europe Parliamentary Assembly of 4 October 2007, No. 1577(2007): “Towards decriminalization of defamation". 
On the other hand, as Estonia has moved along its path to becoming a modern and democratic country, the right to a private life is also essential when it comes to such matters as emergence of new technologies and progress in the realm of the Internet. Media technology can threaten our privacy: in such context, individuals who are confronted with interference in their private life or freedom of expression turn to Estonian courts and then to the Court to decide on these novel issues. ${ }^{*} 52$

Furthermore, the consequences of new dimensions in cross-border human relations and free movement of persons in Europe, especially in the European Union, has, among many positive aspects, also created unfortunate cases concerning, for example, problems of family life such as child abduction ${ }^{*} 53$ and change of a child's father in the entry in the birth register ${ }^{*} 54$.

\section{Retroactivity and lack of foreseeability of criminal law}

there are so far three judgements wherein Estonia was found to be in violation of Article 7 of the Convention: Veeber No. 2 v. Estonia ${ }^{*} 55$, Puhk v. Estonia ${ }^{*}{ }^{6}$, and Liivik $v$. Estonia. ${ }^{*}{ }^{57}$ In the first two cases, the retroactive application of criminal law as well as the lack of clarity and foreseeability in the relevant criminal legislation amounted to a violation of Article 7 (1) of the Convention. Similarly, in the third case, the Court found that the interpretation and application of $\$ 161$ of the Criminal Code, the criminal law applicable at the relevant time and the legal basis for the applicant's conviction, had involved the use of such broad notions and vague criteria that the clarity and foreseeability required of law under Article 7 of the Convention had not been met. As only a few of the Court's judgement deal with Article 7 of the Convention, the Estonian cases are quite significant in that respect.

\section{Re-opening of a case on national level after the Court's judgement}

The relevant articles of the procedural codes for including the possibility of re-opening a case after a violation has been found by the Strasbourg Court ( $\$ 366$ (7) and $\$ 367$ of the Code of Criminal Procedure; ${ }^{*} 8$ Article 702 (8) of the Code of Civil Procedure; Article 240 (8) and 241 (2) of the Code of Administrative Court Procedure) were introduced after the Supreme Court had already ruled it possible to re-open a case where a violation was found by the Strasbourg Court by applying the Convention and Court case law directly. ${ }^{59}$ The legislature followed the Supreme Court and introduced the relevant change, bringing with it the new grounds and legal basis for re-opening. This is why the explanatory letter on the law amending the procedural codes in order to foresee the revision (re-opening) stated expressis verbis among the grounds for the legislative amendments the need to comply and implement the decisions of the Court. ${ }^{* 60}$

${ }^{2}$ Delfiv. Estonia, [GC] no. 64569/o9, 16 June 2015, where the Grand Chamber found no violation of Article 10 of the Convention.

53 The application was declared inadmissible, because the national courts found that there was no information that the child's return from Estonia to Italy would involve a risk of physical or psychological harm or otherwise place her in an intolerable situation. The Court reiterated that such an assessment is primarily the task of the domestic authorities, who enjoy a certain margin of appreciation in that regard. The Estonian courts had examined the risk, including the opportunities of the mother to join the child in Italy during the custody proceedings; see M.R. and L.R. v. Estonia, No. 13420/12, 15 May 2012.

54 As to the latter, see the judgement of the Court in Jussi (Jüssi) Osawe v. Estonia, 63206/10, 31 July 2014. The applicant wished firstly to bring an action against her husband $\mathrm{O}$ seeking a declaration that the entry in the birth register concerning her child's descent from him was incorrect and secondly to bring an action against D, seeking the establishment of her daughter's descent from him. However, since the applicant did not use the remedies available to her in the first set of proceedings, the Court considered her access to a court in the second set of proceedings not to have been restricted in a disproportionate manner.

55 Veeber No. 2 v. Estonia, No. 45771/99, 21 January 2003.

${ }_{56}$ Puhk v. Estonia, No. 55103/oo, 10 February 2004.

57 Liivik v. Estonia, No. 12157/05, 25 June 2009.

58 RT I 2006, 48, 360 - entry into force 18.11.2006. However, it has not been clear how to apply this in practice; see Eerik Kergandberg, Background Paper at the Conference in Riga in 2012 about the Role of Supreme Courts in the Protection of Human Rights. The recent case law of the Supreme Court has, however, shed some light on this; see the Judgment of 3 December 2012 of the Administrative Law Chamber, Case No. 3-3-1-61-12 and of 14 March 2013 of the Criminal Law Chamber of the Supreme Court, Case No. 3-1-2-3-13.

59 Judgement of 6 January 2004 of the Supreme Court en banc, Case No. 3-3-2-1-04.

60 Explanatory letter 545 SE I of 13 December 2004. 
These examples have proved the use of the Convention and the Court's case law as an argument in preparing the Estonian legislation, especially if it is drafted by the executive power, in particular by the Ministry of Justice.

\section{Implementation of the Court's judgements by Estonia}

The judgements finding a violation in respect of Estonia have in general overall been well executed; there are no particular problems with execution under Article 46 (1) of the Convention. As far as the supervision of the execution of the final judgements by the Committee of Ministers is concerned (Article 46 (2) of the Convention), in Estonia the Government agent of Estonia to the Court (a civil servant of the Ministry of Foreign Affairs) presents the action plans and reports to the Committee of Ministers. The execution of the judgements in substance lies, however, within the ministries that are responsible for the area in which the Court has found a violation and are obliged to take the required measures; for example, the introduction of new draft laws to modify the procedural codes is the task of the Ministry of Justice, and to change the judicial practice is in the competence of the courts. The Ministry of Finance is in charge of paying the damages awarded by the Court to the applicant.

In Estonia the Government's agent prepares annual reports about the international case law of human rights protection in Estonia, which includes the overview of the individual applications against Estonia to the Court. ${ }^{*} 61$ There is no special committee of the Estonian Parliament dealing with the Convention and Court case law; however, the members of the parliament who form part of the PACE are up to date about the latest developments concerning the Court.

\section{Additional remarks on application by the Supreme Court of the Convention and the Court's case law}

The first direct reference to a judgement of the Court was made by the Constitutional Review Chamber of the Supreme Court of Estonia on 20 December 1996. The Supreme Court referred to Malone v. United King dom $^{* 62}$ to substantiate its own comprehension of the definition of legality. ${ }^{*} 63$ Ever since, the Supreme Court has made references many times to the Court's case law and, of course, also to the Convention. ${ }^{*} 64$ It has done so even in cases where a national legal regulation was absent by referring directly to the Convention and case law on it. ${ }^{*} 65$ However, the most important examples in this respect are the possibility to re-open a case in which the Court has found a violation and the creation of a remedy for compensation for procedures of unreasonable length. As explained above, recently the legislator has more or less followed the Supreme Court and introduced necessary changes into respective laws.

61 These reports are public and available on the Web site of the Ministry of Foreign Affairs (www.vm.ee) as well as discussed at the Government's sessions and also reflected in press reviews.

62 Malone v. United Kingdom, No. 8691/79, Plenary of the Old Court, 2 August 1984.

63 Judgement of 20 December 1996 of the Constitutional Review Chamber of the Supreme Court, Case No. 3-4-1-3-96, RT O 1997, 4, 28.

64 According to an analysis conducted by the Supreme Court, most of the references of the Supreme Court to the Court's case law were made in criminal cases concerning the fair trial, including length of proceedings, but also in constitutional review (above all, about the issues of effective remedies and excessive court fees) and in administrative law cases concerning some expulsion cases but first and foremost the prison conditions, because the disputes arising from the applications of the inmates are the competence of the administrative courts. Besides the Convention and the Court's case law, also the soft law of the Council of Europe, as, for example, European Prison Rules, has been used actively in the reasoning of the judgements of the Supreme Court. In civil cases the reference to the Convention and the Court's case law has been more limited. The judgements of the Court referred to most often are: Pélisser and Sassi v. France, [GC] no. 25444/94, 25 March 1999; Kudla $v$. Poland, [GC], No. 30210/96, 26 October 2000; Konashevskaya and others v. Russia, No. 3009/o7, 3 June 2010; Reinhardt and Slimane-Kaid v. France, Nos 21/1997/805/1008 and 22/1997/806/1009, 31 March 1998; Kangasluoma v. Finland, No. 48339/99, 20 January 2004; and Sunday Times v. UK (No. 1), No. 6538/74, 26 April 1979. See Eve Rohtmets, Euroopa Inimõiguste Kohtu praktika Riigikohtu lahendites. Kohtupraktika analüüs (The case law of the European Court of Human Rights in the judgements and decisions of the Supreme Court: Analyses of the court practice), Legal Information Department of the Supreme Court, Tartu, 2012.

65 See René Värk; Carri Ginter. Estonia, in: The European Convention on Human Rights and Fundamental Freedoms in Central and Eastern Europe, Leonard Hammer; Frank Emmert (eds), The Hague: Eleven International Publishing, 2012, pp. 183-196. 
To a certain extent one could say that the Supreme Court of Estonia has given legitimacy to its decisions by citing the judgements of the Court and can therefore be considered to have in certain issues taken the lead in incorporating the Convention into the domestic legal system.

More usually the Supreme Court applies the provisions of the Constitution together with references to the Convention in order to support the proper interpretation of the Constitution. The Supreme Court has also referred to the Convention / Court's case law by way of obiter dictum for illustrative purposes. The Supreme Court has well grasped the de facto precedence value or even erga omnes application of the Court's judgements, because most of the case law of the Court that has been referred to by the Supreme Court is not related to the judgements rendered concerning Estonia. One problem in doing so seems to be that the relevant case law of the Court referred to in the Supreme Court judgements, except if it is in Estonian cases (these are all being translated), might not be available in the Estonian language.

On the other hand, the Supreme Court has maintained certain caution in finding, for instance, that the fact that the Court in another judgement has evaluated grounds for arrest in the national law of another state as Convention confirming does not create additional grounds for an arrest in Estonian criminal procedural law, which enumerates exclusively all the relevant grounds for taking into custody and holding in custody. ${ }^{* 66}$

The impact of the Court's case law goes far beyond the referral to the case law of the Court: it can also be said that some methodology used by the Court, for example, to assess the proportionality of a measure has been to a certain extent followed by the Supreme Court in deciding the cases. ${ }^{* 67}$ It can also happen that the Supreme Court has even set higher standards than in the Convention system by stating, for example, that in comparison to Article 2 (1) of Protocol No. 7 of the Convention the right of appeal is guaranteed to a greater extent by $\S 24$ (5) of the Estonian Constitution. ${ }^{* 68}$

Furthermore, the national courts have improved their practice of informing the applicant about the lawyer appointed by the Bar Association as well as reminding the applicant to make contact with the lawyer. This has been done in order to fix the drawbacks pointed out in the case law of the Court. In subsequent cases, the Supreme Court has re-opened the proceedings with the reference to the Andreyev judgement of the Court because there as well the applicants had missed the cassation deadline due to the failure of legalaid appointed lawyers. ${ }^{*} 9$

In another administrative law case, the Supreme Court analysed whether the finding of violation by the Court in a particular case influenced the outcome of the case and whether the situation can be remedied by other means than re-opening and agreed in substance with the Court that the applicant, a prisoner, did exhaust the pre-judicial remedy and his complaint to the prison authorities was sufficiently clear. Therefore, the Supreme Court decided that the re-opening was well-founded and remitted the case to the first instance court. ${ }^{*} 70$

However, sometimes the Supreme Court, although it does analyse in a detailed way whether there are grounds for re-opening, refuses to re-open a case, stressing that re-opening will be justified only if the violation found by the Court could influence the outcome of the criminal case. ${ }^{* 71}$

66 Decision of 10 January 2013 of the Criminal Law Chamber of the Supreme Court, Case No. 3-1-1-127-12.

67 See also Triipan, Martin, Proportsionaalsuse põhimõte Euroopa Liidu õiguses (The Principle of Proportionality in the EU Law), which focuses more on the EU law. Juridica 2006, No. 3, pp. 151-158.

68 Judgement of 18 June 2010 of the Constitutional Review Chamber of the Supreme Court, Case No. 3-4-1-5-10.

69 Judgement of 14 March 2013 of the Criminal Law Chamber of the Supreme Court, Case No. 3-1-2-3-13; Decision of 3 December 2012 of the Administrative Law Chamber of the Supreme Court, Case No. 3-3-1-61-12.

70 Decision of 18 March 2013 of the Administrative Law Chamber of the Supreme Court, Case No. 3-3-2-2-12 (concerning the judgement of the Court in the Julin case).

71 For example, the Judgement of 11 April 2013 of the full composition of the Criminal Law Chamber of the Supreme Court, Case No. 3-1-2-1-13 (request to re-open the case after the violation was found in Leas $v$. Estonia was not accepted) and the Judgement of 29 September 2014 of the Criminal Law Chamber of the Supreme Court in Case No. 3-1-2-2-14 (request to re-open the case after the violation was found in Martin $v$. Estonia was not accepted). 


\section{Impact of the Court's case law in relation to Estonia on general development of precedents at the Strasbourg Court}

Despite the relatively low number of chamber cases concerning Estonia, the Court's case law regarding Estonian problems has still influenced the overall case law of the Court by generating a wider impact on human rights standards and continues to do so with the first Grand Chamber judgement in respect of Estonia in the Delfi case, involving rather new Internet elements.

Most of the references in the case law of the Court to the judgements of the Court made in Estonian cases concern the judgements in Sulaoja $v$. Estonia of 2005 (about the unjustified extension of pre-trial detention) ${ }^{*} 72$, Tammer $v$. Estonia of 2001 (balancing the Article 8 and 10 Convention rights) ${ }^{*} 73$, and Alver v. Estonia of 2005 (about the prison conditions) ${ }^{*} 74$. The Grand Chamber judgements ${ }^{*} 75$ have used the principle developed in the Tammer $v$. Estonia decision stating that, although under Article 10 of the Convention the Contracting States have a certain margin of appreciation in assessing whether interference with the right to freedom of expression was "necessary in a democratic society", this margin goes hand in hand with European supervision, embracing both the legislation and the decisions applying it, even those issued by an independent court. ${ }^{*} 76$

Some of the references to judgements in Estonian cases have become general principles in the constant case law of the Court, such as the Court's stressing that when deciding whether a person should be released or detained pre-trial, the authorities have an obligation under Article 5 (3) of the Convention to consider alternative measures of ensuring his or her appearance at the trial and that the absence of a fixed residence as such does not give rise to a danger of absconding. ${ }^{*} 77$ In assessing whether the treatment inflicted on a prisoner went beyond the "inevitable element of suffering or humiliation" associated with the deprivation of liberty, the Court has, inspired by Alver $v$. Estonia, started to take into consideration inter alia the length of the period during which a person is detained in particular conditions. ${ }^{*} 78$

Judgement material in Leas $v$. Estonia, where shortcomings in the access to materials collected by means of surveillance were pinpointed, has served as a good source of inspiration in cases concerning similar problems in other countries, such as Latvia. ${ }^{*} 79$

Even an inadmissibility decision as in a child abduction case concerning Estonia* 80 has been useful to elaborate on the duties of national judges under the Hague Convention of 25 October 1980 on the Civil Aspects of International Child Abduction and similar EU law: the "Brussels II bis Regulation". ${ }^{81}$

72 For example, Pichuginv. Russia, No. 38623/03, 23 October 2012, para. 104; Yevgeniy Kuzmin v. Russia, No. 6479/o5, 3 May 2012, para. 34; Valeriy Kovalenko v. Russia, No. 41716/o8, 29 May 2012, para. 44; Chumakov v. Russia, No. 41794/04, 24 April 2012, para. 163; Oreb v. Croatia, No. 20824/o9, 31 October 2013, para. 119; Sergey Vasilyev v. Russia, No. 33023/07, 17 October 2013, para. 86; Segeda v. Russia, No. 41545/o6, 19 December 2013, para. 69.

73 For example, Aksu v. Turkey, [GC], Nos 4149/04 and 41029/04, 15 March 2012, para. 65; Mouvement Raelien Suisse v. Switzerland, [GC] no. 16354/06, 13 July 2012, para. 59; von Hannover v. Germany No. 2, [GC], Nos 40660/08 and 60641/o8, 7 February 2012, para. 104; von Hannover v. Germany, No. 59320/oo, 24 June 2004, paras 58-60; Mika v. Greece, No. 10347/10, 19 December 2013, para. 32; Cumpana and Mazare v. Romania, [GC.], No. 33348/96, 17 December 2004, para. 111.

74 Just to give some more recent examples out of many: Khodorkovskiy and Lebedev v. Russia, Nos 11082/06 and 13772/05, 25 July 2013, para. 465; Idalov v. Russia, [GC], No. 5826/03, 22 May 2012, para. 94; Horshill v. Greece, No. 70427/11, 1 August 2013, para. 44; Aksenov v. Russia [dec.] no. 13817/05, 15 January 2013, para. 18; Niecieckiv. Greece, No. 11677/11, 4 December 2012, para. 48.

75 E.g., Von Hannover v. Germany, No. 59320/oo, 24 June 2004, para. 60.

76 Tammer $v$. Estonia, No. 41205/98, 6 February 2001, para. 60.

77 Sulaoja $v$. Estonia, No. 55939/oo, 15 February 2005, para. 64. This judgement is mainly referred to in Russian cases, where the wrong application of Article 5 (3) of the Convention is a constant problem.

78 Alver $v$. Estonia, No. 64812/01, 8 November 2005.

79 Baltins $v$. Latvia, No. 25282/o7. 8 January 2013, para. 47.

$80 \quad$ M.R. and L.R. v. Estonia [dec.], No. 13420/12.

81 Nadolska and Lopez Nadolska v. Poland, [dec.] no. 78296/11, 15 October 2013, para. 102 and also, for example, in the concurring opinion of judge Pinto de Albuquerque to the judgement in the case $X v$. Latvia, No. 27853/o9, [GC.], 26 November 2013. 
It has also happened that the Court has later departed from the earlier approach taken in an Estonian case and therefore a case has been referred to the Grand Chamber. ${ }^{*} 2$

On the other hand, the Court has in Estonian cases not really made use of comparative law and research into the situation in the other Contracting States about the issue of the case under examination. The same can be said about the third-party interventions in Estonian cases, which are not at all common ${ }^{*} 83$, with Delfi $v$. Estonia being an exception that has attracted many third-party interventions. Estonia itself has intervened only few times. ${ }^{*} 84$

\section{Conclusions}

In relation to the Court's case law, it is important to understand that finding by the Court of a violation of the Convention in respect of Estonia is not so much a condemnation "against" the country, but it constitutes in a sense a learning lesson for Estonia's democracy, rule of law, and human rights protection system. However, at the same time, it is quite natural that some of the Court's judgements are more easily accepted than others.

Furthermore, there could well be other difficulties in Estonia that the Court has for various reasons had no chance to deal with. This can be seen in areas where the Court has found a violation against another state but where a similar problem still exists in Estonia - e.g., in relation to prisoners' voting rights. It is important to look at a more global picture of the human rights situation. It is unfortunate that in Estonia, especially in the media and in wider public, still little attention is paid to the case law of the Court concerning other states.

In general, European law has been well accepted in Estonia, especially the Convention and the case law of the Court. This acceptance has, however, emerged gradually: the shift in mentality sometimes has difficulties in keeping up with the democratisation of legislation.

Working from the Estonian examples, one can confirm that the legislature and even more so the executive power and above all the judiciary of Estonia have well realised that the Convention is an inseparable part of Estonia's legal and democratic culture. It has been a logical and self-evident development in the society at large. The Estonian legal environment has been open-minded towards the Convention, although, especially since the Charter of the Fundamental Rights of the European Union (the Charter) became legally binding, in December 2009, it is not always easy for an Estonian lawyer, let alone a common person, to orientate in the framework of the three main and yet so different sources of human rights protection in Estonia: the Constitution; the Convention, and the EU law (the Charter). ${ }^{*} 85$ Estonian courts need to feel that they also are human rights courts, especially in dealing with the facts and Estonian law: domains where the Court cannot and should not act as a fourth or first instance. But the Court should be able to speak not only to the courts as counterparts but also to Estonian people. They as well need to understand the European human rights law.

All in all, Estonia is quite lucky: it does not have particularly worrying human rights problems; not many violations of the Convention are found in respect of Estonia by the Court.

Estonia has also been fortunate to be "saved" from major cases concerning the Soviet past and transformation process, unlike perhaps some others from the East. The case law of the Court in relation to Estonia

82 For example, in Martin v. Estonia, the Court found a violation under Article 6 (1) and (3) of the applicant's defence rights on account of the lack of access during the pre-trial proceedings to the lawyer chosen by the applicants' parents. However, in a similar case, against Croatia, the Court at the Chamber level did not find a violation of Article 6 (1) and (3) and did not follow the approach adopted unanimously in Martin v. Estonia. This case has been brought, and is as of January 2015 pending, before the Grand Chamber.

83 The Government of Russia has intervened when the cases have concerned Russian nationals with politically more sensitive issues, as in Korobov and Others $v$. Estonia, rather than in cases concerning criminals of Russian nationality as such, e.g., Vronchenko v. Estonia.

84 In Agim Behrami and Bekir Behramiv. France, No. 71412/01 and Saramativ. France, Germany and Norway, No. 78166/01 [GC], 2 May 2007, see para. 102, about the Estonian Government's intervention, and in Avotiņš v. Latvia, No. 17502/07, pending before the Grand Chamber.

85 See Laffranque, Julia, Who Has the Last Word on the Protection of Human Rights in Europe? Juridica International XIX, 2012, pp. 117-134. Laffranque, Julia, Who has the Last Word on the Protection of Human Rights in Europe? in Cohérence et impact de la jurisprudence de la Cour européenne des droits de l'homme. Liber amicorum Vincent Berger edité par Leif Berg, Montserrat Enrich Mas, Peter Kempees, Dean Spielmann, Oisterwijk: Wolf Legal Publishers, 2013, pp. 223-244. (Melange) 
reflects a gradual move towards a rule-of-law-based independent and modern country with all its problems and struggles from the past to present. The recent Estonian cases have been dealing with more or less the same issues every ordinary democratic country faces, even to a certain extent with problems of a modern, well-advanced society, such as freedom of expression and privacy rights on the Internet.

Also the Court has been lucky to have Estonia as an exemplary country where the Convention system and the Court's case law have been to a large extent respected and well complied with. But this mutual "happiness", this quite nice two-way street, should not be taken for granted.

The overall image of the Court is a mosaic of images of the Court in all respective countries of jurisdiction: therefore, it is vital that in Estonia the Court is seen as able to manage its workload and that the Court's case law is coming at the right time and place, dealing with the actual and relevant issues. Thus, the Court cannot take the risk of treating the smaller and less problematic countries as less important for the impact of the overall case law and the image of the Court: every person and every case counts.

Instead of conclusions, it is important to look at the future, to move on. The Court's case law is a moving target: it is impossible to make any final deductions, because already between the time when these lines are written and when they are read many new judgements have been made by the Court. Hopefully, all future developments regarding the Court will contribute to the improvement of the protection of human rights, democracy, and the rule of law around Europe. Estonia or any other European country cannot apply the generally recognised principles by choice in its "own way". ${ }^{86}$ One needs a good means of transport in order to move on the two-way street. President of Estonia Toomas Hendrik Ilves, at Estonian Lawyers' Days, on 30 September 2010 spelled out that the rule of law is like a good car that needs constant care, tightening of the loose screws, and replacement of worn parts. ${ }^{*} 7$

I hope that Estonia not only takes good care of its rule of law vehicle but also encourages others to do so: in fact, Estonia's trump in Europe and beyond could be to serve as a model in the protection of human rights. Taking into consideration its experience, geopolitical location, and size, as well as investments in education and historically rooted importance of nurturing intellectual and cultural values, Estonia could be in a very good position to achieve this ambitious goal.

86 See also Glikman, Leon, Häbistamine kogu Euroopa ees (Shame in Front of All Europe), Postimees, 10 April 2012.

87 President Ilves: Õigusriik on nagu hea auto (The State Based on Rule of Law is Like a Good Car), Postimees, 30 September 2010. 